\title{
Розробка письмової форми інформованої згоди пацієнта під час надання послуг із фізичної терапії
}

\author{
УДК 615.8
}

\author{
В. М. Савченко, Г. Д. Харченко, В. В. Керестей, \\ О. Ю. Буряк, Ю. М. Погребняк
}

Київський університет імені Бориса Грінченка, Київ, Україна

\begin{abstract}
Резюме. Мета. Розробити письмову форму інформованої згоди пацієнта під час надання послуг із фізичної терапії. Методи. Аналіз, порівняння і синтез нормативно-правових документів, наукової літератури. Результати. Принцип автономії пацієнта і медичної практики обумовлює потребу регламентувати відносини пацієнта і фізичного терапевта під час надання послуг із фізичної терапії. Це вимагає застосування добровільної інформованої згоди пацієнта на проведення фізичної терапії. Наразі в Україні розроблено та затверджено форму первинної облікової документації № 003-6/о «Інформована добровільна згода пацієнта на проведення діагностики, лікування та на проведення операції та знеболення» й інструкція щодо заповнення цієї форми. Проте вона не придатна для оформлення правових відносин між фізичним терапевтом та пацієнтом. Визначено основні особливості застосування такої згоди та розроблено її зразок для застосування у практичній діяльності фізичних терапевтів. Запропоновано письмову форму добровільної інформованої згоди пацієнта на проведення фізичної терапії.

Ключові слова: пацієнт, інформована згода, фізична терапія, послуги.
\end{abstract}

\section{Development of a written form of a patient's informed consent during the provision of physical therapy services}

V. M. Savchenko, H. D. Kharchenko, V. V. Kerestey, O. Yu. Buryak, Yu. M. Pogrebnyak Borys Grinchenko Kyiv University, Kyiv, Ukraine

Abstract. Objective. To develop a written form of a patient's informed consent during the provision of physical therapy services. Methods. Research methods analysis, comparison and synthesis of legal documents, scientific literature.

Results. The principle of autonomy of the patient and medical practice determines the need to regulate the relations between a patient and a physiatrist during the provision of physical therapy services. This requires the use of a patient's informed consent to physical therapy. At present, the form of primary accounting documentation № 003-6 / o «Informed voluntary consent of the patient to diagnostics, treatment and surgery and anesthesia» and instructions for filling in this form have been developed and approved in Ukraine. However, this form is not suitable for legal relations between a physiatrist and a patient. The main features of the application of such consent have been determined and its model for application in the practice of physiatrists has been developed. A written form of a patient's voluntary informed consent to physical therapy is proposed. Keywords: patient, informed consent, physical therapy, services. 
Постановка проблеми. Нині в Україні фрізична терапія - сорормована і легітимна професія з особливими професійними аспектами клінічної діяльності та освіти, яка належить до системи охорони здоров'я [10]. Згідно з нормативними документами Світової конфедерації фрізичної теpaniï (World Confederation for Physical Therapy) зміст фрізичної терапії передбачає надання послуг приватним особам і населенню з метою розвитку, збереження та відновлення максимальної рухової і фрункціональної спроможності людини впродовж усього життя. Фізична терапія також охоплює надання послуг у випадках, коли рухова і фрункціональна спроможність людини послаблена чи втрачена внаслідок старіння, перенесеної травми, хвороби або негативного впливу навколишнього середовища [20].

Надання таких послуг потребує розв'язання етичних питань. Етичні принципи вимагають від фрізичного терапевта визнання права пацієнта/ клієнта чи його законного опікуна на самостійне ухвалення рішень щодо отримання послуг із фрізичної терапії [20]. Саме тому постає питання, чи $\epsilon$ потреба в додатковому правовому обгрунтуванні застосування щодо людей різноманітних фрізіотерапевтичних чинників і допоміжних засобів. Це питання витікає також із того, що на цей час описано деякі особливості інорормованої згоди в різних галузях медицини - педіатрії, хірургії, акушерстві, стоматології та психіатрії $[3,4,6,7]$.

Інформована згода пацієнта - процедура, за допомогою якої суб'єкт добровільно підтверджує свою згоду на проведення щодо себе різноманітних медичних втручань, офіційно затверджених регулятором у сорері охорони здоров'я. Добровільна інформована згода на медичне втручання вважається одним 3 основних елементів сучасної системи правового регулювання медичної сфери обслуговування. Вона є правом пацієнта й обов'язком медичного працівника, що здійснює медичне втручання $[1,5,8,9]$.

Постановку питання про потребу отримання інформованої згоди пацієнта на проведення фрізичної терапії обумовлює важливий аспект діяльності фрізичного терапевта - його освіта. В Україні освітні програми з фрізичної терапії хоча й належать до галузі знань "Охорона здоров'я», але не $\epsilon$ суто медичними. Тобто фрізичний терапевт не $\epsilon$ офріційно медичним працівником, але має право здійснювати діагностичні процедури та впливи фізичними чинниками щодо пацієнта в межах своїх компетенцій [10]. Затверджена Міністерством охорони здоров'я України форма первинної облікової документації №003-6/о «Інформована добровільна згода пацієнта на проведення діаг- ностики, лікування та на проведення операції та знеболення» містить у назві вказівку на «...лікування та на проведення операції...», що $€$ суто лікарськими компетенціями [11]. Проте ця форма не придатна для оформлення правових відносин між фрізичним терапевтом та пацієнтом.

Робота виконана у Київському університеті імені Бориса Грінченка відповідно до державної бюджетної науково-дослідної теми «Критерії оцінки функціонального стану та ефективності фрізичної терапії осіб з хворобами і травмами опорно-рухової та нервової систем (на основі Міжнародної класифрікації фрункціонування, обмеження життєдіяльності та здоров'я)» (номер держреєстрації 0119U000307).

Мета дослідження - розробити письмову форму інформованої згоди пацієнта під час надання послуг із фрізичної терапії.

Методи дослідження: аналіз, порівняння і синтез нормативно-правових документів, наукової літератури.

Результати дослідження та їх обговорення. Нині в Україні нормативно-правовими актами, зокрема Законом України «Основи законодавства України про охорону здоров'я», закріплено принцип автономії пацієнта [9]. Цей принцип передбачає право пацієнта: одержати інформацію про стан свого здоров'я, медичні втручання, які можуть здійснюватися щодо нього; надати інформовану згоду на ці втручання, частково або повністю відмовитися від медичних втручань/ послуг; самостійно обрати методи лікування, лікувальний заклад та персонального лікаря [2].

Наразі наказом Міністерства охорони здоров'я України № 110 від 14 лютого 2012 р. (у редакції № 549 від 8 серпня 2014 р.) передбачено порядок заповнення форми первинної облікової документації № 003-6/о «Інформована добровільна згода пацієнта на проведення діагностики, лікування та на проведення операції та знеболення» [11]:

1. Форма № 003-6/о (інформована згода) заповнюється пацієнтом, який звернувся в заклад охорони здоров'я та дає згоду на проведення діагностики і лікування, у разі потреби на оперативне втручання та знеболення. Це здійснюється у присутності лікаря-куратора даного закладу охорони здоров'я.

2. Пацієнт повинен власноруч вказати своє прізвище, ім'я, по батькові.

3. Лікар-куратор має повідомити пацієнту інформацію щодо плану діагностики та лікування, надати в доступній формі інфоомацію про ймовірний перебіг захворювання, а також про наслідки за умови відмови від лікування. 
4. Свою згоду на запропоноване лікування та діагностику пацієнт та лікар-куратор засвідчують підписами.

Проте вказана інформована згода пацієнта $\epsilon$ суто лікарською і не передбачає згоду на проведення фрізичної реабілітації/терапії, послуги 3 якої надає фрахівець без медичної освіти. Розроблення такої спеціальної форми потребує урахування того, що фрізичний терапевт може працювати за двома організаційними фоормами:

- найманий працівник у державній чи приватній установі на відповідній посаді зазвичай у складі мультиреабілітаційної команди;

- самостійно як приватний підприємець, надаючи послуги з фрізичної терапії.

У першому випадку всі питання отримання у пацієнта добровільної інфрормованої згоди вирішуються «централізовано» адміністрацією установи, застосовується затверджена МОЗ України форма інфоормованої згоди (форма № 003-6/о), від установи згоду підписує лікар-куратор. У цьому разі ффізичний терапевт зазвичай не підписує інформовану згоду і можна констатувати, що повну юридичну відповідальність за пацієнта несе його лікар-куратор.

У другому випадку фрізичний терапевт надає послуги з фрізичної терапії як самостійна юридична особа і вже сам несе повну юридичну відповідальність за пацієнта. Наш досвід, який грунтується на опитуванні декількох десятків фрізичних терапевтів, засвідчує, що фрізичні терапевти застосовують різноманітні фооми інформованої згоди пацієнта на надання послуг з фрізичної терапії. Хтось застосовує затверджену форму № 003-6/о, дехто - рекомендовану фоорму на професійних курсах підвищення кваліфрікації, хтось - форму власної розробки.

Отже, наразі не створено офріційно затвердженої державним регулятором чи рекомендованою професійною асоціацією фоорми інфоормованої згоди пацієнта на надання послуг з фрізичної терапії. Ми вважаємо, що фрізичний терапевт, який інфоормує пацієнта про засоби фрізичної терапії та потім іх застосовує, має надавати пацієнту спеціальну форму добровільної інформованої згоди та підписувати іï. Це захистить як пацієнта, так і фізичного терапевта у випадках виникнення будь-яких ускладнень під час здійснення фрізичної терапії.

Інформована згода пацієнта на проведення фрізичної терапії, на наш погляд, має бути обов'язковою і для фрізичного терапевта, і для пацієнта. Така форма має містити ключові положення про усвідомлення пацієнтом усіх характеристик фрізіотерапевтичного втручання, яке здійснюватиметься щодо нього: ризики та ускладнення, які можуть виникнути під час здійснення фрізіотерапевтичного втручання; застереження щодо недотримання рекомендацій фрізичного терапевта, що може несприятливо позначитися на стані здоров'я пацієнта; вказівка, що пацієнт мав змогу поставити будь-які запитання стосовно стану свого здоров'я, засобів фізичної терапії, які будуть застосовуватися щодо нього, а також одержав вичерпні й зрозумілі на них відповіді; вказівка, що пацієнт мав достатньо часу на ухвалення рішення про згоду. Інформована згода пацієнта має оформлюватися в письмовій формі. Щодо фоорми інформованої згоди та тексту, який має міститися в ній, можна стверджувати, що для фрізичної терапії наявна i затверджена МОЗ України форма інформованої згоди № 003-6/о $є$ непридатною. За кордоном існують різні фоорми такої інфоормованої згоди. Найбільш повне вирішення питання про «фізіотерапевтичну» інфоормовану згоду пацієнта нами знайдено в Італії. G. Galeoto et al. [15] запропонували чотири фооми інфоомованої згоди, які адаптовані до потреб фрізіотерапевта та $\epsilon$ специфічними для основних галузей реабілітації. Ці автори запропонували фрорми інфрормованої згоди для ортопедичної, неврологічної, респіраторної і кардіологічної реабілітації. Кожна фрорма інформованої згоди містить стандартизовано структуровану інформацію:

1) загальна інформація про пацієнта (паспортні, клінічні, соціальні дані тощо, які вносить фрізичний терапевт);

2) функціональна оцінка пацієнта;

3) фізіотерапевтичне втручання;

4) загальні ризики реабілітаційного лікування;

5) ймовірні специфрічні ускладнення;

6) нелікувальні ризики;

7) інша інформація на запит пацієнта;

8) текст згоди пацієнта на реабілітаційні втручання;

9) текст згоди пацієнта на обробку персональних даних.

На нашу думку, зміст інформованої згоди не варто перевантажувати. В неї достатньо включити лише ті положення, що чітко прописують відносини між фрізичним терапевтом та пацієнтом, зазначені вище: про план проведення фізичної терапії, характеристики фрізіотерапевтичних втручань, які будуть застосовані, конкретні ризики та ускладнення, що можуть виникнути під час здійснення фрізіотерапевтичних втручань. Інші переваги та недоліки фрізіотерапії бажано розповісти пацієнту під час усної бесіди та надати йому відповідний друкований i відеоматеріал. 
Крім предметної фрізіотерапевтичної складової, інфоорована згода пацієнта зазвичай містить також згоду на використання та обробку його персональних даних. У формі інфоормованої згоди № 003-6/о, затвердженій МОЗ України, лише пацієнт $\epsilon$ стороною такої домовленості і дає згоду на використання своїх персональних даних. Зарубіжні ж автори [15] в інформованій згоді навпаки пишуть про обов'язки фрізичного терапевта перед пацієнтом щодо використання його персональних даних відповідно до закону: «... я хотів би повідомити вас, що стосовно закону ... дані, які ви надаєте мені для правильного складання форми інформованої згоди, будуть використовуватися як для визначення вашого поточного стану здоров'я, так і для адміністративних цілей і будуть зберігатися в моєму архіві» [15].

Синтезуючи проаналізовані вітчизняну та зарубіжні інформовані згоди пацієнта, для обгово- рення пропонуємо форму (бланк) добровільної інфрормованої згоди пацієнта на проведення фрізичної терапії, яка може застосовуватися в діяльності фрізичних терапевтів.

Обговорюючи результати дослідження, можна констатувати, що у світовій практиці правові та етичні питання щодо інформованої згоди на оцінювання та лікування пацієнтів у фрізичній терапії розв'язано ще у 1980-х рр. Спочатку усвідомили, що у своїх судових позовах пацієнти ставляться до фрізичних терапевтів так само, як і до лікарів, вимагаючи надання безпечних фрізіотерапевтичних послуг [14]. Згодом розробили правові та етичні принципи щодо інформованої згоди пацієнтів у випадках надання фрізіотерапевтичних послуг $[16,19]$. У ті роки була обговорена ситуація, коли медичні працівники та особи без медичної освіти, що надають допомогу пацієнтам та які безпосередньо не підписують інформовану

\section{ІНФОРМОВАНА ЗГОДА ПАЦІЄНТА НА ПРОВЕДЕННЯ ФІЗИЧНОЇ ТЕРАПІЇ}

Я,

(прізвище, ім'я, по батькові)

підтверджую, що отримав(ла) зрозумілу для мене інформацію від фізичного терапевта

(прізвище, ім'я, по батькові)

про проведення мені (моїй дитині) необхідного фізіотерапевтичного втручання.

Перебуваючи у

(найменування лікувально-профілактичного закладу, фізична особа-підприємець)

я був(ла) ознайомлений(а) із запропонованим мені (моїй дитині) планом проведення фізичної терапії. Мені доступно роз'яснили і я розумію умови, методи, мету, характер та наслідки фізіотерапевтичного втручання.

Я повідомляю, що усвідомлюю ризики та ускладнення, які можуть виникнути або бути пов’язані з фізіотерапевтичним втручанням. Я проінформований(а) про можливі зміни фізичної терапії в разі виникнення проблем із моїм (моєї дитини) здоров'ям або зміни перебігу захворювання. Мені роз'яснено, що недотримання рекомендацій фізичного терапевта може несприятливо позначитися на стані мого (моєї дитини) здоров'я. Я усвідомлюю, що без моєї співпраці та готовності дотримуватися деяких правил поведінки та процедур, зазначених фізичним терапевтом, терапія не може бути успішною в довгостроковій перспективі.

Я мав(ла) змогу поставити будь-які запитання стосовно стану мого (моєї дитини) здоров'я, засобів фізичної терапії, які будуть застосовуватися, та одержав(ла) вичерпні й зрозумілі мені на них відповіді. Я мав(ла) достатньо часу на ухвалення рішення про згоду на запропоновану фізичну терапію.

Я даю згоду на внесення до інформаційної системи, яка ведеться закладом охорони здоров'я / фізичною особоюпідприємцем, моїх персональних даних, зокрема даних щодо стану мого (моєї дитини) здоров'я. Я погоджуюсь із використанням та обробкою моїх персональних даних за умови дотримання їх захисту відповідно до вимог Закону України «Про захист персональних даних».

Фізичний терапевт зі свого боку зобов'язується, що надані персональні дані пацієнта будуть використані лише для оцінювання поточного стану здоров'я пацієнта, для цілей здійснення програми фізичної терапії та адміністративних цілей i будуть зберігатися лише в архіві фізичного терапевта.

Пацієнт

(підпис пацієнта або його законного представника; прізвище, ім’я, по батькові; документ, що підтверджує право представляти інтереси пацієнта)

Фізичний терапевт

$$
\text { (підпис) }
$$

Третя особа

$$
\text { (підпис) }
$$

Дата 
згоду з пацієнтом, у судових позовах пацієнтів можуть бути визнані такими ж відповідальними, як і особи, що підписують інфрормовану згоду. Аби захиститися від судових позовів, фрізичним терапевтам рекомендувалося брати у пацієнтів інформовану згоду на проведення фрізіотерапевтичних впливів [12, 13].

Як в Україні, так і в деяких країнах Східної Європи в нормативно-правовому полі неповною мірою відрегульована діяльність спеціалістів, що надають послуги у сорері охорони здоров'я, але не мають медичної освіти. Це стосується і фрізичних терапевтів, які 3 деяким запізненням усвідомили потребу використання інорормованої згоди пацієнта в процесі фрізичної реабілітації [17]. N. Roman et al. [18] навели дані, що лише 40,8 \% фрізіотерапевтів Румунії завжди прагнуть отримати інформовану згоду пацієнта на початку фрізіотерапії, водночас 16,3 \% фрізіотерапевтів ніколи не застосовували цю законну вимогу пацієнта у своїй професійній діяльності.

\section{Література}

1. Александрова ОЮ. Проблемы реализации права пациента на информированное добровольное согласие при медицинском вмешательстве (возможные пути решения). [Problem with realization of patients right for informed voluntary agreement before the medical intervention (possible solutions)] Вестник эстетической медицины. 2009, 8 (3):82-7.

2. Аніщенко МА. Принцип автономії пацієнта: проблеми правової регламентації в Україні [Principle of patient's autonomy: problems of legal regulation in Ukraine]. Актуальні питання фармацевтичної і медичної науки та практики. 2018; 11, 2 (27): 225-9.

3. Бисюк ЮВ. Некоторые правовые аспекты оказания экстренной медицинской помощи больным пожилого и старческого возраста [Legal aspects of urgent medical help for elderly and old sick patients]. Успехи геронтологии. 2008; 21 (1): 165-8.

4. Варшавский ЮВ, Китаев ВВ, Ершов ВВ. Добровольное информированное согласие пациента на лучевое исследование как этическая и медиколегальная проблема [A patient's voluntary informed consent to radiological examination as an ethical and medical problem]. Радиология практика. 2008; 3: 44-9.

5. Лиссабонская декларация относительно прав пациента [Declaration of Lisbon on Patients' Rights. It was adopted by the 34th World Medical Assembly. (1981)]. Принята 34-й Всемирной медицинской ассамблеей. Лиссабон, Португалия, сентябрь/октябрь 1981 г. URL: https://zakon. rada.gov.ua/laws/show/990_016\#Text (дата звернення: 25.05.2021).

6. Магсумов ТА, Магсумова РМ. Добровольное информированное согласие пациента на медицинское вмешательство в стоматологии: проблемы практического применения [A patient's voluntary informed consent to medical intervention in dentistry: problems of practical application]. Актуальные проблемы гуманитарных и естественных наук. 2010; 4: 310-2.

7. Марков ЮІ, Жежер АО. Інформована згода в клінічній практиці [Informed consent in clinical practice]. Медицина невідкладних станів. 2019; 2(97): 143-9. https://doi: 10.22141/2224-0586.2.97.2019.161656.

8. Медведева ЛМ, Вешнева СА. Информированное согласие как реализация прав пациента: ретроспектива проблемы [The informed consent
Отже, право пацієнта на інформовану згоду під час фрізичної терапії не може жодним чином ігноруватися, оскільки є юридичним аспектом діяльності орізичного терапевта та основною цінністю невід'ємних прав людини на життя і здоров'я.

Висновки. Принцип автономії пацієнта в медичній практиці обумовлює потребу регламентувати відносини пацієнта і фрізичного терапевта під час надання послуг з фрізичної терапії. Це вимагає застосування добровільної інформованої згоди пацієнта на проведення фрізичної терапії. Нині в Україні такої фрорми інформованої згоди не розроблено. Запропоновано письмову фрорму добровільної інформованої згоди пацієнта на проведення фрізичної терапії.

Перспективи подальших досліджень. Подальші дослідження можуть полягати у вивченні результатів практичного застосування фрізичними терапевтами запропонованої інфрормованої згоди пацієнта на проведення фрізичної терапії.

Автори заявляють про відсутність конфлікту інтересів.

as realization of the patient's rights: retrospective of the problem]. Биоэтика 2012; 1(9): 22-4.

9. Основи законодавства України про охорону здоров'я: Закон України [Fundamentals of Ukrainian legislation on health care: Law of Ukraine]. Biдомості Верховної Ради України. 1993;4: 19. URL: https://zakon.rada.gov.ua/ laws/show/2801-12/conv\#n348 (дата звернення: 25.05.2021).

10. Про внесення змін до Довідника кваліфікаційних характеристик професій працівників: наказ Міністерства охорони здоров'я України від 13.12.2018 № 2331 [On amendments to the Dictionary of Qualification Characteristics of Workers' Professions: Order of the Ministry of Health of Ukraine]. Охорона здоров'я. Випуск 78. URL: https:// moz.gov.ua/uploads/1/9223-dn_20181213_2331.pdf (дата звернення: 25.05.2021).

11. Про затвердження фрорм первинної облікової документації та інструкцій щодо їх заповнення, що використовуються у закладах охорони здоров'я незалежно від форми власності та підпорядкування: наказ МО3 України від 14.02.2012 № 110 [On approval of the forms of primary accounting documentation and instructions for their completion, which are used in health care facilities regardless of the form of ownership and subordination: Order of the Ministry of Health of Ukraine]. URL: https://zakon.rada.gov.ua/laws/show/ z0697-12\#n2 (дата звернення: 25.05.2021).

12. Banja JD, Wolf SL. Malpractice litigation for uninformed consent Implications for physical therapists. Physical Therapy. 1987 Aug; 67(8): 6-9 https://doi: 10.1093/ptj/67.8.1226. PMID: 3615592.

13. Copnell G. Informed consent in physiotherapy practice: it is not what is said but how it is said. Physiotherapy. $2018 \mathrm{Mar}$; 104(1): 67-71. https://doi: 10.1016/j.physio.2017.07.006. Epub 2017 Aug 7. PMID: 29352579.

14. Fantaci ES. Application of the locality rule and implications for malpractice actions against physical therapists. Physical Therapy. 1982 May; 62(5): 604-8. doi: 10.1093/ptj/62.5.604. PMID: 7071160.

15. Galeoto G, Mollica R, Astorino O, Cecchi R. Informed consent in physiotherapy: proposal of a form. G Ital Med Lav Ergon. 2015 Oct-Dec; 37(4) 245-54. PMID: 26934810. 
16. Janet A. Coy. Autonomy-Based Informed Consent: Ethical Implications for Patient Noncompliance. Physical Therapy. 1989 October 1;69(10):82633. https://doi.org/10.1093/ptj/69.10.826.

17. Milinkovic I, Majstorovic B. Patient's right to informed consent in republic srpska: legal and ethical aspects (with special reference to physical rehabilitation). Med Law. 2014 Dec; 33(4): 127-46. PMID: 27351050.

18. Roman N, Miclaus R, Rogozea L. Ethical considerations about informed consent in physiotherapy in Romania. Med Pharm Rep. 2019 Oct; 92(4): 362-7. https://doi: 10.15386/mpr-1223. Epub 2019 Oct 25. PMID: 31750436.

v.savchenko@kubg.edu.ua

h.kharchenko@kubg.edu.ua

v.kerestei@kubg.edu.ua

o.buriak@kubg.edu.ua

y.pohrebniak@kubg.edu.ua
19. Ruth B. Purtilo. Applying the Principles of Informed Consent to Patient Care: Legal and Ethical Considerations for Physical Therapy. Physical Therapy. 1984 June 4. Volume 64. Issue 6. P. 934-7. https://doi.org/10.1093/ ptj/64.6.934.

20. Strategic Plan 2017-2021. World Confederation for Physical Therapy. URL: https://world.physio/sites/default/files/2020-07/Strategic_Plan_ Final_070716.pdf (дата звернення: 25.05.2021). 